\title{
21 Days of Social Synergistic Pilot Survey on Community Participation to Determine the Level Virulence of COVID-19 in Africa before Re-Opening of the Education Sector in an efficiency, Affordable and Sustainable Approach
}

\section{Maurice B Silali*}

Maseno University, Kenya

*Corresponding Author: Maurice B Silali, Maseno University, Kenya.
Received: May 23, 2020

Published: June 29, 2020

(C) All rights are reserved by Maurice B Silali.
21 days of Synergistic community participation survey [2] to determine reopening of education sector in Africa remain a key cradle to create psycho social confidence in parents, pupils and students since they left school colleges and universities without completion of their first term or semester exams in mid-march 2020 after the confirmation of the first case of COVID-19 virus [9]. 21 days study period is the maximum incubation period of COVID - 19 Virus to show sign and symptoms in an infected individual. The success of re-opening education sector may need a comprehensive and holistic synergistic practical participation survey of all cohorts of stakeholders to promote a quality rapid mind healing and reconciliation [1-3] among the various infected and affected communities in the Global population and Sub Saharan Africa. The target population of the candid study survey will be mainly via reopening the churches, mosques, open air markets and other social amenities closed down, on curfew or lockdown due to attributed pandemic of COVID-19 Virus [6,9].

Thus basically first and foremost, the various Governments may stop/ lift up all total bans imposed on religion congregations, suspend issues of curfews and lockdown in affected countries for 21 days of close surveillance and monitoring of signs and symptoms of the COVID -19 resurgent in any community, and enhance other form of human socialization among different communities as it was before the era of COVID-19 pandemic, with limited or no utilization of PPE [hand washing, sanitize and face masking], to prevent inhalation or contact the air borne diseases, because the quality uptake of PPEs in majority of public institutions is limited/ poor, and they cannot afford and sustain these PPE for a whole term/ semester [4,9]. During the 21 days period of the practical study on effect of the COVID-19 virus we will measure the subjective indicators of COVID-19 virus at both community household and facility level by qualitative approach on the health seeking behavior of a specific community on COVID -19 manifestations [4,5]. The outcome of the study survey will be determine by key informants at each level of small communities, Padres Imams, pastors, chiefs meetings, house and community holds of our society in context of our society norms, if the subjective indicators on COVID-19 virus remains low and less virulence [4], the Government may consecutively reopens schools, colleges and university respectively, and not in a stepped manner, since it will not compromise the academia in basic and secondary levels from the lesson learn from above 21 days participatory baseline survey[8].

We may not use the flattening of the curve on COVID-19 infection of the health population, simple because it is an artificial curve mainly attributed with the various Government restrictions of movement of persons from one place to another, and not associated with the real time infection in the population health. Such flattened artificial curve may be associated with the significant future mass reinfection in population, compared to the natural flattened curve determined by the entire population health passive and herd immunity achieved through community infection and affected country $[5,8]$. Note over $86 \%$ of COVID - 19 patients in Africa remain asymptomatic, thus benign conditions which may associated well to super spreaders characters in other continents.

This 21 days timely and practical synergistic participatory study survey will determine the reopening of the education sector which is economical, efficient and affordable [3,9],to a each specific Nation, without use of such Community COVID-19 virulence Approach Model, the schools, colleges and universities may open in a major hidden associated psycho social challenges among the education stakeholders, specifically students and parents, whereby we may realize the sporadic of COVID-19 virulence resurgence abruptly in the society, hence education sector will be closed again for disease management which may turn out to be worse for the many Governments in developing countries as seen in developed countries such as Asia and Europe. [9]. 


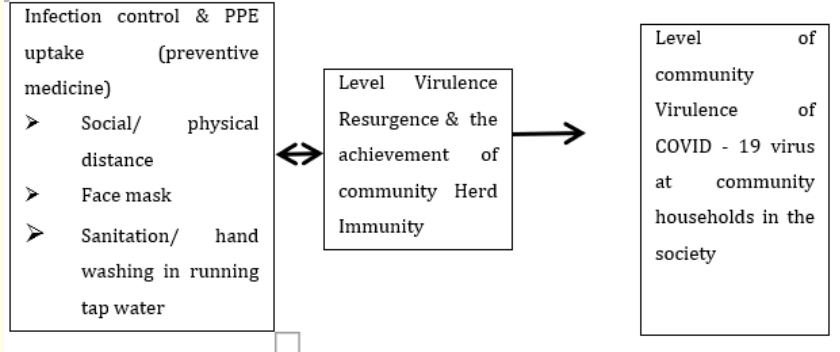

Figure 1: Community COVID - Virulence 19 Model Approach

Note that the virulence level of COVID -19, Case Fatality Rate [3] by mid of May 2020, for instance in Kenya was 4.9\%, highest in east Africa region. Whose growing data from $\mathrm{MOH}$ indicate the over $85 \%$ of Kenyan population health are asymptomatic with COVID-19 virus, which means it's benign and individual have no clinical manifestation of the Virus unless ignited by other opportunistic infections or non-communicable diseases [3]. Thus reasons why some parts of the Asian content decided to repatriate African back to their Continent in April 2020, because Africans were attributed with being super spreaders of the COVID-19 pandemic virus, which need more research to confirm the case. [9].

Last but not least, WHO, in May, 2020, said that no one can predict when the COVID-19 virus disease will end in our society because diseases always manifest in human population, so long human being are existing the disease will basically exist like measles, HIV, Ebola in west Africa. Advantage of air borne disease when infected the body systems [cardiovascular and lymphatic] have specific cells to react and defense via provision of immunity or provision of vaccines. [Attenuate antigens] to prevent and control which take slightly longer period $[5,8]$.

Good to note that COVID-19 virus, an airborne whose primary vital organ is lungs thus why we advise population health to wear face masks and keep physical and social distance when in public, like other viral infections has no cure, quality healing is determined by early detection and supportive management of early and mild clinical presentations before goes to severe: septic shock that need ICU care because at this level the COVID -19 Virus now attacks secondary organs such as heart , kidney and other lymphatic glands. [8].

\section{Bibliography}

1. Haines A and S Kuruvilla. "Bridging the implementation gap between knowledge and action for health". Bulletin of the World Health Organization 82.10 (2004): 724-732.

2. Singleton A., et al. "Approaches to social research". Oxford University, Press: New York (1998).

3. Southerland B. "Participation Research in Natural resources, social-economic”. Trainer's Guide for Participatory learning and Action London (1998).

4. Maurice B Silali. "Factors Associated with Low Virulence in the Infective COVID-19 Virus in Africa with the Pandemic infection Rise". Acta Scientific Medical Sciences 4.4 (2020): 130-134.

5. Leon Gordis. "Principles of epidemiology". Third edition (2004).

6. WHO. "Health challenges are influenced by bad health practices which forms major difficulty in achieving quality healthcare in developing countries" (1997).

7. WHO. "Effects of SARs on the population health in southern China" (2005).

8. WHO. "Preventive and treatment of the novel corona viruses in Wuhan china" (2019).

9. WHO. "African countries move from COVID-19 readiness to response as many confirm cases" (2020).

\section{Assets from publication with us}

- Prompt Acknowledgement after receiving the article

- Thorough Double blinded peer review

- Rapid Publication

- Issue of Publication Certificate

- High visibility of your Published work

Website: www.actascientific.com/

Submit Article: www.actascientific.com/submission.php Email us: editor@actascientific.com

Contact us: +919182824667 